\title{
SYK wt Allele
}

National Cancer Institute

\section{Source}

National Cancer Institute. SYK wt Allele. NCI Thesaurus. Code C52220.

Human SYK wild-type allele is located within 9q22 and is approximately $94 \mathrm{~kb}$ in length.

This allele, which encodes tyrosine-protein kinase SYK protein, plays a role in coupling activated immunoreceptors to signal transduction events that mediate diverse cellular responses, including proliferation, differentiation and phagocytosis. 